\title{
FOLK NARRATIVES AND LEGENDS AS SOURCES OF WIDESPREAD IDIOMS: TOWARD A LEXICON OF COMMON FIGURATIVE UNITS
}

\author{
Elisabeth Piirainen
}

\begin{abstract}
The subject matter of this article is widespread idioms originating from folk tales and old legends that once were elements of the folklore of various European language communities but later fell into oblivion. The motifs of these tales survived in currently known idioms of many languages of Europe and beyond and thus contribute to constituting a part of the Lexicon of Common Figurative Units.
\end{abstract}

Key words: animal tales, comical stories, common figurative units, fables, folk narratives, intertextuality, languages of Europe, legends, Schwundstufe, widespread idioms

\section{NARRATIVES AND FIGURATIVE UNITS OF THE LEXICON}

It is a well-known fact in folklore and paremiology that various genres of verbal folklore like fairy tales, legends, riddles etc., on the one hand, and figurative units of the lexicon (i.e. proverbs and proverbial phrases, the latter also known as idioms) on the other, are often inextricably interrelated with each other. Several studies have been devoted to the interrelation between narratives and their "zerograde" truncated forms (German Schwundstufe) in proverbs and idioms (e.g. Röhrich 1960; Mieder 1986), and the mutual relationship between proverbial expressions and narratives, especially fables, has been a matter of intensive semiotic and inter-textual research (cf. Perry 1959; Permiakov 1979, Grzybek 1989; Carnes 1988, 1991, among others). A tale in its simplest form can be identical with a proverb, with the relationship going in both directions. On the one hand, stories (particularly fables) have been derived from already existing proverbs, from antiquity up to early modern times. On the other hand, a story in its summarised form can live on in a proverb or an idiom, even if the knowledge of this story has been forgotten for a long time. 
It is generally less known that there are various idioms of this latter kind: idioms originating from allusions to folk narrations, comical tales, legends, etc., which once were widespread and well-known across several European languages but fell into oblivion in the course of history. These narratives (i.e. their truncated forms) survived not only in idioms of some individual languages but in almost "similar" idioms of a large number of present day languages of Europe and beyond.

\section{WIDESPREAD IDIOMS IN EUROPE AND BEYOND}

Cross-linguistic lexical-semantic "similarities" of the idioms of some languages have now and then come to the notice of phraseology researchers but have not been studied systematically until recently. The similarities are usually explained as contact-induced borrowings from one language into the other. Even more: according to a persistent misconception, the tendency of languages to converge with respect to their idioms is seen as a sign of the increasing influence of the English language in the wake of the so-called globalisation. Whether the uniformity of idioms across different languages is related to the influence of English in our times or has completely different causes can only be determined by means of data gained from comprehensive research on a large number of languages. Some of the results, that emerged from the international project Widespread Idioms in Europe and Beyond, over the last few years, may be regarded as one small contribution in this area.

One of the goals of the project was to identify the core inventory of idioms that exist in many European languages (and beyond) in the same or a very similar lexical and semantic structure. First, a theoretical framework and a suitable meta-language had to be developed (cf. Piirainen 2009, 2010). The next objective was to systematically discover widespread idioms (WIs) across as many languages as possible. Unlike the cross-linguistic phraseology which usually focuses on two or three randomly selected languages, all European languages accessible to idiom research were included. For this purpose, a network of competent collaborators was established, and questionnaires with potentially "common European idioms" were sent to about 250 experts of various languages. We have received data for 73 languages spoken in Europe, among them 55 Indo-European, 11 Finno-Ugric ${ }^{1}$ and five Turkic languages as well as Maltese, Georgian and Basque, including 41 major and 32 lesser-used languages.

It was completely unpredictable which of the idioms would actually be widespread and which would fall short of our criteria. The questionnaires produced about 360 units that are truly widespread across 40, 50 or more languages of Europe and beyond. This set of idioms was then categorised according to their 
historical origins, i.e. their cultural foundations and the chronological layers to which they may be assigned. It turned out that a large number of WIs had already been widespread from the Middle Ages and following centuries onwards. The number of WIs, rooted in a genuinely modern layer and which may be traced back to recent Anglo-American influence, seems to be very small.

The main goal of the project is now to compile the data, given by our informants on the background of this historical-etymological classification, in order to create a lexicon of the widespread idioms which we call the Lexicon of Common Figurative Units ${ }^{2}$ (cf. Piirainen forthcoming).

\section{COMMON FIGURATIVE UNITS AND INTERTEXTUALITY}

Further details resulted from this cultural-historical assignment of each widespread idiom: more than half of the entire inventory of our "common European idioms" (about $177 \mathrm{WIs}$ ) falls under the umbrella term of intertextuality. By this we understand the relationship of an idiom with an already existing, mostly identifiable text as its cultural and historical origin. Several types of intertextuality can be distinguished, depending on whether the connection between the textual source and the idiom is close or rather loose.

First, there are direct quotations from an individual text which gradually developed into idioms but still can be identified as literary fragments by their wordings, for the most part. Widespread idioms of this provenance range from quotations from classical authors (e.g. to combine business with pleasure, tracing back to Horace's De Arte Poetica, verse 343) or biblical verses (by the sweat of one's brow, Genesis 3:19) to various literary works (much ado about nothing, the title of Shakespeare's comedy).

The second group is not as easy to single out, namely widespread idioms precursors of which were in circulation as early as in ancient times. The simultaneous occurrence of a given saying, in several ancient sources, is a sure indication that it was already proverbial at that time. A prominent example is the idiom the die is cast, which is often regarded as an utterance coined by Caesar. As the sources show, Caesar did not create but quoted this phrase which is in fact much older, already current and understood in its figurative meaning in Greek antiquity. ${ }^{3}$ This second group includes WIs of biblical origin, used proverbially in the Bible itself.

The largest number of intertextually related WIs, however, goes back to once well-known stories, summarising a certain text passage or the general idea of a text (cf. the first section). This form of intertextuality is particularly important for the development of common European idioms. The knowledge 
of the narratives, side by side with the proverbial phrases, has greatly supported their wide dissemination. Let us briefly consider the different types of stories which have mainly contributed to the widespread use of idioms, before we will have a closer look at WIs originating from post-classical folk narratives and old legends.

About ten idioms, popular in many current European languages, are rooted in Greek mythology; they are allusions to legends about gods and heroes, events surrounding the Trojan War or the Herculean tasks, as recorded by Greek and Roman poets (to be the Achilles' heel; to sweep the Augean stables; like the sword of Damocles hanging over sb.). Little attention has been paid to idioms originating in other types of stories that have been frequently retold since antiquity, such as the WI (to know) the place where the shoe pinches. It is an allusion to Plutarch's comical tale (told in the Coniugalia Praecepta, ca. $22 \mathrm{AD}$ ) about the Roman Aemilius Paulus who was blamed for divorcing his wife, with whom he seemed to have lived happily, and answered "no one knows where the shoe pinches like the wearer".

Various Bible stories, particularly from the Old Testament, contributed to the oldest layer of common European idioms (forbidden fruit; to worship the golden calf; to have feet of clay). Furthermore, several currently well-known WIs are documented in tales of both antiquity and the Bible, which indicates that the phrases were already widely known in the Hellenistic cultural area (e.g. a wolf in sheep's clothing which goes back to Aesop's fable and gained wide dissemination by the Sermon of the Mount, when Jesus refers to a similar fable, Matthew 7:15).

Other narrative sources of common European idioms are fables of the Aesopic type (to strut in borrowed plumes; to enter the lion's den; to fish in troubled waters), fairy tales, which are partly treated as literature (to be a bird in a gilded cage; to run with seven-league boots; an ugly duckling), and post-classical works of world literature (the most prominent WI of this provenance is to tilt at windmills which summarises the gist of Cervantes' famous novel Don Quixote). In contrast to all these (partly well-known) literary sources the traditions of folk tales as foundation of common European idioms have been ignored for the most part.

\section{WIDESPREAD IDIOMS IN FOLK TALES AND LEGENDS}

This section deals with widespread idioms that can mainly be attributed to various traditions of folk narration, partly post-classical tales, although parallels in works of antiquity may well exist. These idioms originate from allusions to stories that once were widespread but fell into oblivion. The stories, how- 
ever, survived in their truncated form in very well known idioms of many current languages. Among the 177 widespread idioms that developed by means of intertextuality, the group of WIs rooted in popular narratives is rather small. We can distinguish three groups, following the underlying type of story, namely idioms that chiefly go back to traditional jests and comical tales, to once popular animal tales and to old myths and legends which resulted in concepts of fabled animals. What the three groups have in common is the fact that not only the idioms are widespread but that the motifs of the tales themselves are elements of the folklore of various European language communities.

For reasons of space short comments on the linguistic specifics of the WIs (their structure and figurative meaning) will be given in smaller type. We will present the full data only for three examples (see the Appendix). In the other cases, we restrict ourselves to a small selection of idiom equivalents across the languages. There is no English equivalent of the idioms (3-4); here the German version will be quoted.

\section{Jests and comical tales}

The idioms (1-6) can be traced back to jester's tales and the "topsy-turvy world", where fools try the impossible (adýnaton) and nonsensical things take place. Idiom (1) is a good example to illustrate how the interaction between narratives and old proverbs can lead to the birth of a greatly widespread idiom.

\section{(1) to carry water in a sieve}

'to try to achieve a goal by using a totally inappropriate tool which inevitably leads to failure and seems very strange and unusual'

There are diverse folktales that tell the story of a hero who is forced to solve the impossible task of catching and carrying water in a sieve (or a leaky vessel, a basket). This old motif is spread across Europe (cf. Grimms' folktale Master Pfriem, KHM No. 178) and can also be identified in the Greek myth of Hades, where the daughters of Danaos had to scoop water into a jar that had holes in it. Thus, the origins of the idiom lie in a variety of narrations and proverbs that were common throughout the ancient world and the Middle Ages. ${ }^{4}$ Equivalents of the idiom as well as the textual sources behind it were spread across Europe in the early times.

The broad figurative meaning given above encompasses several partly diverging aspects. The idioms of different languages vary with respect to the individual aspects of this meaning that they highlight, which may be due to the diverse strands of tradition of the underlying narrative motif. The idioms show some lexical variation in the verb phrase (CARRY and SCOOP), while the nouns WATER and SIEVE are mostly invariant. Here are some examples, all meaning literally 'to carry (the) water in/with a sieve': Swedish bära vatten $i$ ett såll, German Wasser in einem Sieb tragen, Romanian a căra apă cu 
ciurul, Lithuanian sietu vandeni nešioti, Russian носить воду решетом, Slovak nosit' vodu v koši, Sorbian z křidu wodu nosyć, Albanian merr ujë me shoshë, Estonian sõelaga vett kandma, Tatar иләк белән су ташу, Azerbaijani süzqəcdə su daşımaq.

\section{(2) to put the cart before the horse}

'to put things in the wrong order or set the wrong priorities, to mistake the effects for the cause, to reverse the right or natural order of things'

Idiom (2) belongs also to the context of a "world turning upside down", where senseless and ludicrous things take place. The scenario of putting a horse or an ox behind the cart, or the cart before the team, was a popular folklore motif. It occurs in the Carmina Burana and other texts, also in the Grimms' folktale Master Pfriem (cf. (1)) in which in a man's dream horses are harnessed to the back of a wagon. The motif can also be found on tapestries and misericords in late medieval art. As proverbial phrases, similar images have been used in various languages since the Middle Ages. Ancient proverbs and narrations linked to this motif may have supported its wide distribution. ${ }^{\mathbf{5}}$

The data collected by our informants show that the languages focus on either the HORSE or the oxen concept. The first group of idioms can be roughly translated by 'to put/ harness the cart/carriage before the horse': Norwegian spenne vogna foran hesten, German den Wagen vor das Pferd spannen, Russian запрягать телегу впереди лошади, Czech zapŕahat koně za vůz, Hungarian lovak elé fogja a kocsit, Moksha Mordvin крандазтьфталу алашать кильдемс. The next idioms can be roughly translated by 'to put the cart before the oxen': Breton eno e oa an denn war-lerc'h an arar, French mettre la charrue devant les bœufs, Occitan bitâ el shariô dran dlou bioû, Romansh metter il char avant ils bovs, Spanish poner antes el carro que los bueyes, Romanian a pune carul înaintea boilor, Albanian vë parmendën para qeve.

(3) den Ast absägen, auf dem man sitzt ('to saw off the branch upon which one is sitting'), i.e. 'to deprive oneself of the basis for one's livelihood; to lose out through one's own fault'

The old comical tale of a man sitting on the branch of a tree and cutting it off was well-known since the Middle Ages in many European languages, ranging from Finnish to Greek and from Livonian to Spanish. ${ }^{6}$ Idiom (3) is often listed together with other proverbial phrases that express foolish actions harmful to oneself and are reported by Roman authors (e.g. "to knock the bottom out of one's own ship" or “to burn one's own harvesting”, cf. Spalding 1959: 77). The core of this story can be recognised in the rich image evoked by the complex sentence of all idiom equivalents.

The idioms of most languages can be literally translated as 'to saw off the branch sb./ you/one(self) is/are sitting on', e.g. Icelandic saga greinina sem e-r situr á, Dutch de tak afzagen waarop men zit, Italian si taglia il ramo su cui si siede, Aromanian sh-talje lumachia pi cai shade, Latvian (no)zāgét zaru, uz kura pats sē, Belorussian пілаваць 
сук, на якім сядзіш, Czech podřiznout si větev, na které sedí, Serbian сећи грану на којој седиш, Estonian seda oksa saagima, millel istud. Somewhat different verbs are used in Lithuanian kirsti šaką, ant kurios sed $d i$ 'to cut off the branch oneself is sitting on', Polish podcinać gałąź, na której si siedzi 'to prune the branch you are sitting on' or Georgian ra totzets zis, imas jriso 'he cuts off the branch he is sitting on' and Romanian $a$-şi tăia craca de sub picioare 'to cut off the branch below the legs'. Deviant structures have also been reported for Slovak pílie konár pod sebou 'to saw off the branch below oneself' and Hungarian (ön)maga alatt vágja a fát 'sb. cuts down the tree under him/ her(self)'.

(4) mit Kanonen auf Spatzen schießen ('to fire at sparrows with cannons'), i.e. 'to use disproportionate means on an insignificant matter; to take stronger action than is necessary to deal with a problem or situation'

The exact origins of this idiom are unclear. Most probably it is connected to old folktales about a fool who tries to kill a fly (flies, bees, etc.) with an unsuitable instrument (axe, cannon, sword or gun) and accidentally kills the person whom the insect had been bothering. ${ }^{7}$ In medieval times, similar expressions are recorded for Italian, French and English, where the animal is not a sparrow but a fly (TPMA 3, 296), as is the case in the tales. The idea is that of someone attacking a very small creature with an inappropriately heavy weapon, e.g. with a sword, a crossbow or a falcon, and causing damage.

Our informants have cited variants with the concepts FLY and MOSQUITO for present times, e.g. Dutch met een kanon op een vlieg / mug schieten, West Frisian mei in kanon op in mich sjitte or Spanish matar moscas a cañonazos and Macedonian убива муви со топ, both meaning literally 'to kill flies with cannons', and Finnish ampua tykillä hyttysiä 'to shoot mosquitoes with a cannon'.8 Most other idioms literally mean 'to shoot/fire with cannons/with a cannon at sparrows', e.g. Swedish skjuta sparvar med kanon(er), French brûler sa poudre aux moineaux 'to fire one's powder at sparrows', Ladin ti stlopetè cun canuns ai spoc, Romansh trair cun chanuns sin paslers, Italian sparare ai passeri con un cannone, Lithuanian šaudyti iš patrankos $i$ žvirblius, Russian стрелять из пушки по воробьям, Slovak ist's gul'ometom na vrabce 'to go with machine gun against sparrows', Macedonian убива муви со топ 'to kill flies with cannon', Hungarian ágyúval lö verébre, Moksha Mordvin кирьхкснень/озяснон лангс пушкаса ляцендемс 'to fire one's powder for sparrows'.

(5) to sell the skin before you have caught the bear

'to count on future benefits that may never materialise; to divide expected profits etc. from a job that has not yet been accomplished'

The idiom refers to an old anecdote that was retold by La Fontaine (Fables V, 20) but later fell into oblivion. It is the tale of two travelling hunters who want to pay for their lodging with the skin of a bear that has been seen in the area but has not been shot yet. The story (erroneously ascribed to Aesop) appeared 
in print for the first time in Lorenzo Astemio's (Laurentius Abstemius') Hecatomythium in 1492 (cf. Wesselski 1928: 88-107). The equivalents of the idiom are dated or obsolete in some languages. Following the image of the tale, they have partly preserved the complex sentence structure. In Slovak, the concept BEAR has been replaced by WOLF.

Here are some examples: Icelandic selja skinnið áður en björninn er unninn 'to sell the skin before a bear has been overcome', Swedish sälja skinnet innan björnen är skjuten and Dutch de huid verkopen voor de beer geschoten is, both 'to sell the skin before the bear is shot', French vendre la peau de l'ours avant qu'on ne l'ait pris and Italian vender la pelle dell'orso prima d'averlo preso, both 'to sell the skin of the bear before one has got it', Spanish vender la piel del oso antes de cazarlo 'to sell the bear's skin before hunting it', Romanian a vinde blana ursului din pădure 'to sell the skin of the bear in the forest', Latvian (sa)dalīt nenošauta lāča ādu 'to share (out) the skin of a bear that has not been shot', Russian делить шкуру неубитого медведя 'to deal the skin of the not-killed bear', Slovak predávae kožu vlka, ke ho ešte nechytili 'to sell the skin of the wolf before one has got it', Hungarian elöre iszik a medve börére 'sb. drinks on the skin of the bear in advance', Estonian laskmata karu nahka jagama 'to deal the skin of the not-killed bear'.

\section{(6) to look for a needle in a haystack}

'to look for something that is impossible to find; to be bothered with searching without any prospect of success'

There are many folktales of vain searches for objects. Probably, the idiom refers to one of them, although the story of a fool who is hunting for a needle in a haystack is not as widespread. Grimms' fairy tale Clever Hans (KHM No. 32 ) tells about a fool who puts a needle into a hay cart. Here we want to point to the Yiddish idiom (Appendix 1) which uses the concept HAYWAGON. There may be a connection with an old proverb (Si acum quaereres, acum invenisses 'Who wants to search a needle, would also find it', reported by Plautus and Menander 238), although the element HAY is missing here. ${ }^{9}$

The full data reported by our informants are presented in the Appendix 1 below, illustrating that idiom equivalents are remarkably widespread. They exist not only in most of the European standard languages but also in a number of the minor and minority languages and even in some non-European languages. The causes of the "popularity" of this idiom in all these languages are still unclear. It is most probable that the idioms go back to one and the same textual source, although this source has not been established definitely.

Two further widespread idioms belong in the context of "the world upside down" and comical tales. Both idioms have been the topic of comprehensive studies. Therefore, it is sufficient to point to these studies here. The first WI, to build castles in the air 'to make unrealistic plans for the future, to have unfounded hopes and expectations', has several sources; one of them is a folktale, spread 
all over Europe in different versions. The story is about persons, lost in their daydream, who make great plans for the future but quarrel over details and lose everything (see Mieder 2010 for details).

Trokhimenko (1999) investigates into the second idiom, wie ein Elefant im Porzellanladen ('like an elephant in a china shop'), i.e. 'behaving in a rude way, causing damage by one's clumsy behaviour'. It may be rooted in tales about a man and his donkey entering a potter's shop, and various proverbs related to this story, well-known in antiquity.

\section{Animal tales}

Animal tales are traditional folk stories in which animals act like human beings. Unlike animal fables in Greco-Roman antiquity (fables of the Aesopic type), they were told for their own sake, as entertainment. Fables of the Aesopic type are distinguished by their moralising intention. The purpose of these fables is to illustrate a truth by means of a story. It is for this reason that Ben Edwin Perry (1959: 20ff) considers animal tales and fables two very different forms of art and products of different cultures. In our material there are some widespread idioms that most probably go back to once well-known animal stories, otherwise their wide distribution across the European languages and beyond cannot be explained, cf. (7).

\section{(7) to belfight like cat and dog}

'(of two people who know each other well) to frequently have violent arguments with each other, to keep quarrelling and get very angry with each other most of the time'

The motivation of this idiom may be seen in the observation of animal behaviour: it gives the impression that both animals are constantly arguing. However, the rivalry between cats and dogs is the topic of various once well-known European narratives in which the animals are said to have been friends at one point but certain events have led to their enmity. The story is at the same time an "etiological tale", i.e. it gives account of animals' behaviours, for example "as from now on, cat and dog are each other's worst enemies." already richly documented in medieval texts of various vernacular languages (see TPMA 6, 273ff).

See Appendix 2 for the full data. The idiom is exceptionally widespread. There are records for equivalents in at least 68 European languages, among them most of the lesser used languages that we analysed (the Inari Saami idiom was reported as a loan translation from Finnish) as well as several non-European languages. Variants are restricted to the constituent inversion, which is normal for similar binomials across languages, and the choice of verb. Our informants have listed a number of different 
verbs (to be / live / behave / quarrel / understand each other, etc.). Only a selection of them has been presented below. A truncated form (like cat and $\mathrm{dog}$ ) and nominalised form ( $a$ cat-and-dog life 'a life of frequent or constant quarrelling') exist as well.

\section{(8) to play cat and mouse (with sb.)}

'to stall someone off, letting him/her wait for a (negative) decision; to alternate harshness and leniency in one's treatment of a helpless victim'

The roots of this idiom lie in the observation of animal behaviour: cats tend to play with the living mice they caught for quite a while, letting them go a foot or so away and then catching them again before killing their prey for good. The cat's play with a mouse, its physical superiority, which is set against the intellectual superiority of the mouse, has been the topic of various folk tales (such as the Ysengrimus, among others) and parables that were once widespread across Europe. It has also been present in proverbs since medieval times. ${ }^{11}$

The idiom occurs in 53 of the European languages considered here. ${ }^{12}$ Some informants reported variants with GAME, like Hungarian macska-egér játékot qüz vkivel 'sb. plays a cat-mouse-game with sb.' or Turkish kedi fare oyunu 'cat mouse game'. In the following, the literal translation is omitted for those idioms that mean 'to play cat and mouse with sb.': Norwegian leke katt og mus med noen, Swedish leka katt och råtta med ngn. 'to play cat and rat with sb.'13, Luxembourgish Kaz a Maus spillen mat engem, Yiddish shpiln zikh vi a kats mit a moyz 'to play as a cat with a mouse', Welsh chwarae â rhywun fel cath â llygoden 'to play with sb. like a cat with a mouse', French jouer au chat et à la souris avec qqn., Catalan jugar al gat $i$ al ratoli amb algú 'to play the cat and the mouse with sb.', Aromanian tracã, ca matsa cu shoariclu 'to play like a cat with a mouse', Latvian spēlējas kā kaķis ar peli ar kādu 'to play with sb. as the cat with the mouse', Russian играть с кем в кошки мышки, Kashubian bawic sã z kims w kòta i mësz 'to play with sb. cat and mouse', Bulgarian играя си на котка и мишка с някого, Albanian luaj si macja me miun me dikë 'to play cat with the mouse with sb.', Greek

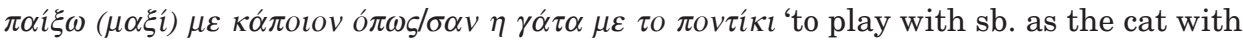
the mouse', Estonian kellegagi kassi ja hiirt mängima, Komi-Zyrian шырӧн-каньӧн ворсны кодкӧдкӧ, Mari пырыс ден коляла модаш 'to play cat-mouse', Karaim mačy byla syčan kibik ojnama 'to play as a cat with mouse', Tatar мэче белэн тычкан уены уйнау 'to play cat and mouse', Azerbaijani siçan-pişik oynamaq 'to play cat (and) mouse', Georgian k'at'a-tagvobanas tamashi 'to play cat-mouse', Maltese jilg'ћab tal-gurdien u tal-qattus 'to play cat and mouse'; Basque katu eta saguaren jolasean ibili 'to play cat and mouse'.

\section{(9) as poor as a church mouse}

'very poor, having no wealth and few possessions'

Economy or poverty is the subject of several folk tales in which the protagonist is a mouse (e.g. The Town Mouse and the Country Mouse, a motif also attri- 
buted to a fable of Aesop). The tale Cat and Mouse in Partnership (KHM No. 2) seems most closely connected to idiom (9) because it is set in a church, where cat and mouse together hide a little pot of fat under the altar for the winter but the cat eats the fat and the mouse remains "poor". It is probable that an old proverbial expression was another basis for this idiom. ${ }^{14}$

Our informants have cited two main idiom variants: with the concept Mouse and with the concept RAT. Only Icelandic has both variants: fátækur eins og kirkjurotta / kirkjumús. The areal distribution reveals some regularities: RAT can be found in the North Germanic languages, in Dutch and Breton, in the Baltic and North Finnic languages, while all Slavonic languages use the variant with MOUSE. Examples with RAT: Norwegian fattig som en kirkerotte, Dutch zo arm als een kerkrat, Breton bezañ paour evel ur razh iliz, Provençal paure coume un gàrri de glèiso, Latvian nabags kā baznīcas žurka, Lithuanian biednas kaip bažnyčios žiurkè, Estonian vaene kui kirikurott, Karelian kö̈̈hü ku kirikönrottu; examples with Mouse: Scots a puir wee kirk moose, North Frisian so aarem ü̈̈s en müs uun a sark, Luxembourgish aarm sin wie eng Kiechemaus, Romansh pover sco ina mieur-baselgia, Romanian la fel de sărac ca un şoarece de biserică, Russian беден как церковная мышь, Slovak chudobný ako kostolná myš, Polish biedny jak mysz kościelna, Kashubian biédny jak kòscelnô mësz, Croatian siromašan kao crkveni miš, Serbian сиромашан као црквени миш, Macedonian како црковен глушец, Hungarian szegény, mint a templom egere, Moksha-Mordvin ашу кода церькунь шеер.

\section{Fabled animals}

The roots of the following widespread idioms lie in age-old semiotisations of animals that were handed down through various legends and books on natural history since ancient times. One of the most famous works is the 37-volume Naturalis historia of Pliny the Elder (23-79 AD), a remarkable attempt to summarise all the knowledge known to the Romans at that time. The early Christian canonical compendium of animal symbolism Physiologos (ca. 200 AD), which was translated into Latin around the year 400 and subsequently into many other languages, or medieval beast epics have also contributed to the semiotisations of animals. The legendary behaviours of the phoenix, ostrich, lynx and crocodile were passed on in this way; they led to the formation of proverbial phrases and left traces in today's Lexicon of Common Figurative Units, although their origins may be lost in the mists of the distant past. Again, not only the idioms but most notably the underlying narrative motifs have been widespread since earliest times.

\section{(10) to rise like a phoenix from the ashes}

'to emerge as new from something that has been destroyed; to find renewal in destruction' 
Idiom (10) belongs to the oldest layer of common European figurative language. The phoenix was a mythical oriental bird. It was adored by the Egyptians as an incarnation of the sun god. For the Greeks (first mentioned by Hesiod, ca. $700 \mathrm{BC}$ ), it was a symbol of eternal rejuvenation and immortality. Herodotus (485-425 BC) tells the story of the phoenix as a bird that burns itself in its nest of spices every five hundred years. The myth of its rebirth and rise from the ashes to the sky was first narrated by Pliny the Elder in his Naturalis historia (10.2.3ff). The phoenix found its way into Christian allegory by means of the Physiologos and writings of early Christian poets and Church Fathers. The legend was alive in the Middle Ages when the phoenix became a symbol of resurrection in arts, painting and beast epics (cf. Öberg 2009).

Equivalents of idiom (10) exist in most of the 41 standard languages included in the WI project but only in few of the lesser-used varieties. As it belongs to a high register of language, there is no place for it in the less official languages. The idiom often appears in truncated form as "to resurrect/rise (again) from the ashes" (Dutch uit zijn as herrijzen, Slovak vystúpie z popola, Finnish nousta tuhkasta) or as a simile "like a phoenix from the ashes" (Icelandic eins og Fönix úr öskunni, Belorussian як феникс 3 пеплу, Albanian si feniksi nga). Most of the further examples can be roughly translated as 'to rise like a/the (bird) phoenix (from the ashes)': Norwegian reise seg som en (fugl) føniks (av asken), Spanish renacer de las cenizas como el Ave Fénix, Romanian a renaște ca pasărea Phoenix din propria cenuşă, Russian возникать как феникс из пепла/ возродиться из пепла как птица-феникс, Polish powstać jak Feniks z popiołów, Croatian dići se (kao feniks) iz pepela, Macedonian воскреснува како феникс од пепелта, Bulgarian възкрьсвам като феникс от пепелта; Albanian ringjallet si Feniksi, Hungarian fönixként támad fel hamvaiból, Estonian fööniksina tuhast tõusma, Azerbajani simurq quşu kimi alovdan yenidən yaranmaq, Georgian peniksivit perplidan agdgoma.

\section{(11) to hide/bury one's head in the sand}

'to pretend a problem does not exist and deliberately refuse to accept the truth about something unpleasant'

Idiom (11) goes back to the old mistaken belief that the ostrich hides its head under (one of its) wings (in other versions: in a bush, in the sand) at the first sign of danger, as if it did not want to see the danger. Although there is an observation of nature behind this myth, ${ }^{15}$ it is due to the old semiotisation of the bird. Pliny the Elder writes about the ostrich's foolish behaviour in his Naturalis historia (10.1) that the bird imagines, when it has thrust head and neck into a bush, that the whole of its body is concealed. This has later been taken up in the Physiologos (24.3: 259): "when it lays eggs it puts its head in the sand" and other natural history and literary works. ${ }^{16}$

The three ancient and medieval ideas of the ostrich's fabled behaviour - it was believed to put the head under its WINGS, into a BUSH or in the SAND - has 
left traces in the idioms of present-day languages. The wING version appears in Spanish meter/esconder la cabeza bajo el ala/debajo del ala 'to put the head under/below the wing' and Catalan amagar el cap sota l'ala 'to hide the head under the wings', while the BusH version is still present in the Finnish idiom panna päänsä pensaseen 'to put one's head into the bush', with the same figurative meaning (probably supported by the alliteration, so common in Finnish phraseology). In most languages, however, there is a version with sAND.

The following idioms can be roughly translated as 'to stick/put/thrust the/one's head in the sand': Icelandic stinga höfðinu i sandinn, West Frisian de kop yn it sân stekke, Luxembourgish de Kapp an de Sand stiechen, Romansh chatschar il chau en il sablun, Czech strkat hlavu do písku, Sorbian hłowu do pěska tyknyćltykać (kaž štrus), Croatian zabiti glavu u pijesak (kao noj), Serbian главу у песак, Bulgarian завирам глава в пясъка, Hungarian homokba dugja a fejét. The next idioms mean approximately 'to hide the/one's head in the sand': Norwegian gjemme hodet $i$ sanden, Latvian paslēpt galvu smiltīs, Russian прятать голову в песок, Polish chować głowę w piasek, Estonian pead liiva alla/sisse peitma, Moksha Mordvin (страус лаца) шувар алу пря кяшендемс, Basque (ostrukak bezala) nork bere burua lurpean ezkutatu. Some idioms roughly mean 'to bury the/one's head in/under the sand': Welsh claddu pen yn y tywod, Italian nascondere la testa sotto la sabbia, Galician enterrar a cabeza na area, Portuguese esconder a cabeça na areia (como a avestruz), Romanian a-şi îngropa capul în nisip, Lithuanian galvą ì smèli kišti, Turkish başını kuma gömmek.

\section{(12) to be lynx-eyed}

'to have extremely sharp, penetrating eyes, good powers of vision'

Idiom (12) cannot be interpreted on the basis of today's knowledge about the lynx. The animal's eyes are not sharper than those of other animals of the Felidae family. The legend of the sharp-eyed lynx came into being due to a number of historical "accidents". In Greek mythology, good powers of vision were ascribed to Lynkeus, one of the Argonauts. It is recorded in Horace's I. Epistle (1.28) that he was so sharp-sighted, that he could see through the earth and distinguish objects that were miles away. Lynkeus' name has been connected with the similarly sounding Greek word $\lambda \hat{\gamma} \gamma \xi$ 'lynx'. Again, this semiotisation of the lynx was spread as "scientific" knowledge by various writers: Pliny called the lynx "the most clear sighted of all quadrupeds" (Naturalis historia 8.28) while Plutarch and other scholars added the idea that the lynx can penetrate through trees and rocks with its sharp sight. Konrad von Megenberg praises the lynx's acuity of vision and hearing in his influential Das Buch der Natur (ca. 1350). Christian medieval symbolism connected the lynx with "vigilance, watchful alertness". This symbolic knowledge has almost completely been lost in the course of the following centuries but survived in figurative units like idiom (12). 
Equivalents of the idiom show different structures like "to have (the) eyes of a lynx" (French avoir des yeux de lynx, Italian avere gli occhi di lince, Spanish tener los ojos de lince), 'to have lynx-eyes' (German Luchsaugen haben, Dutch lynxogen hebben) or similes (e.g. German Augen haben wie ein Luchs, Slovak mat' oči ako rys, both literally 'to have eyes like a lynx', Czech vidět jako rys 'to see like a lynx'), all meaning figuratively 'to have extremely sharp eyes, good powers of vision'. The old semiotisation of LYNX can be found in one-word metaphor, in the sense of 'a person with good powers of vision, a watchful, clever person', and in idioms like German aufpassen wie ein Luchs 'to watch like a lynx', meaning figuratively 'to be very attentive and vigilant' (cf. Dobrovol'skij \& Piirainen 2005: 272, 281f).

\section{(13) to weep/shed crocodile tears}

'to show false or pretended sadness, to display insincere grief; to pretend that one is weeping'

According to ancient legends, crocodiles weep pitifully like a child and shed insincere tears of sorrow in order to lure their victims and when devouring them. There is a physiological background to this: crocodiles make a moaning sound and, after eating, shed excess salt from glands located just beneath the eyes, giving the impression of tears. These legends of crocodiles are believed to be of classical origin. Pliny the Elder and Seneca both give rather fantastic accounts of the crocodile's wiles. The legends were later expanded as "scientific" knowledge across Europe from the Middle Ages onwards (at a time when crusaders became acquainted with real crocodiles for the first time) and the crocodile became the symbol of feigned friendship. In his Das Buch der Natur (ca. 1350), Konrad von Megenberg describes the crocodiles' behaviour "when it kills a person, it weeps over him" (wenn ez aines menschen ertoett, sô waint ez in). The legend appears also in the famous Book of Travels (ca. 1356) attributed to Sir John Mandeville. The proverbial phrase was spread across the European languages by the humanists, by Erasmus, and other influential authors. ${ }^{17}$

For the full data see Appendix 3. As our research has shown, equivalents of the idiom are extremely widespread. They are known in at least 55 European languages and also in various non-European languages, with nearly the same lexical and semantic structure. The majority of these languages primarily use the nominal phrase "crocodile tears", meaning 'an insincere display of grief, hypocritical sorrow'. While all the standard languages and various smaller languages analysed show quite a consistent picture, only some of the minor languages go their own way. With respect to this very wide dissemination of the idiom, several aspects seem to come together here. The idiom goes back to legends passed on from antiquity, on the one hand, and via other Asian narrative traditions, on the other, into various cultural areas of Europe, Asia and North Africa. However, there has not been any research on the route that the idiom equivalents have taken to get into the individual contemporary languages, whether it was through old traditional legends once well-known in the Indian, Arabic and European areas or based on a more recent layer of borrowing. 

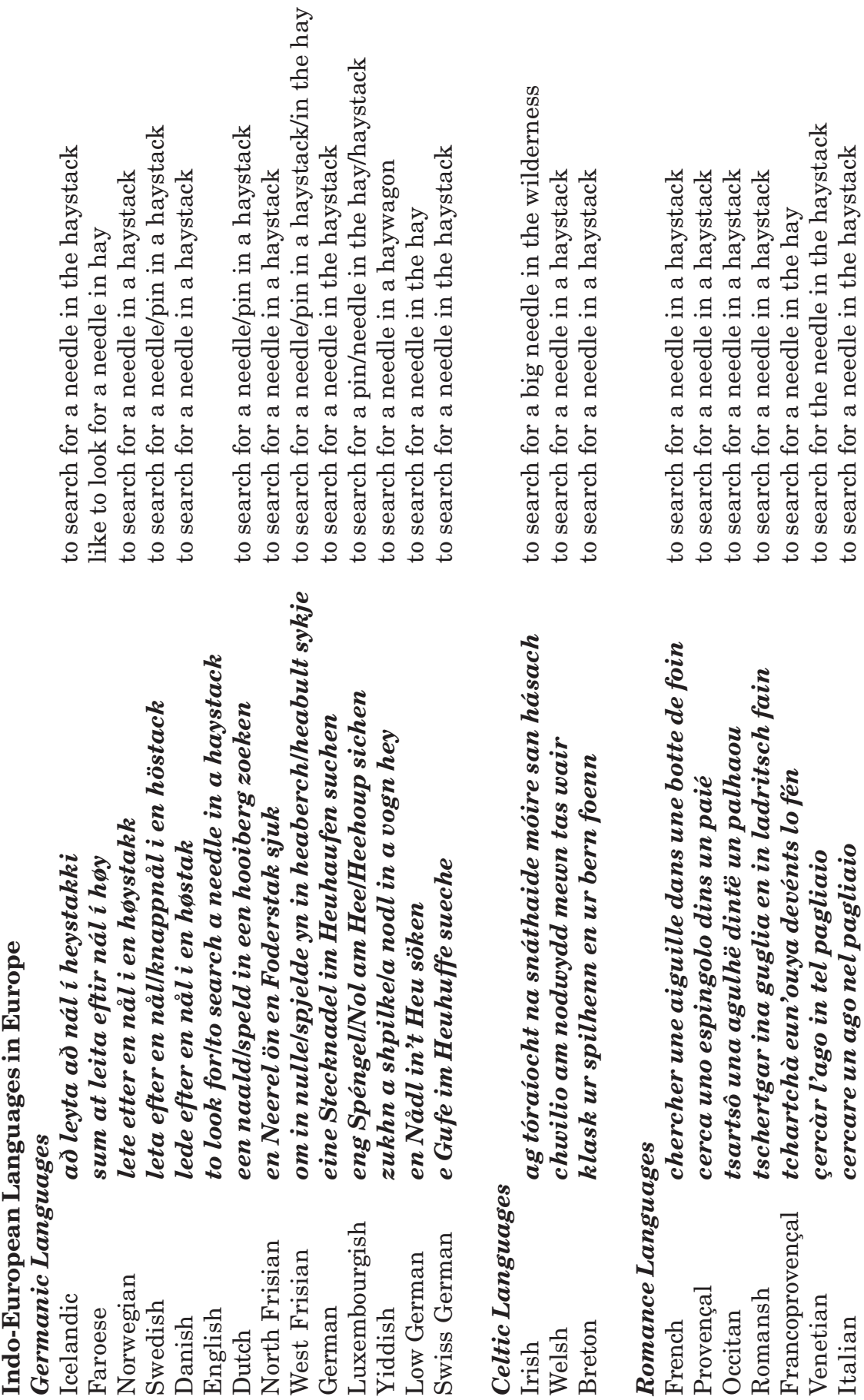


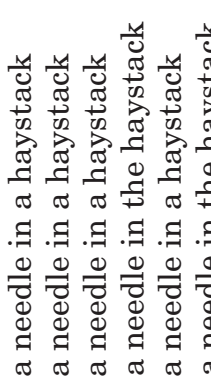

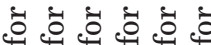

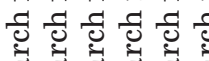

đై

오오오 오요 오

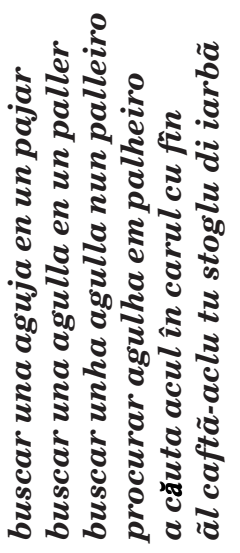

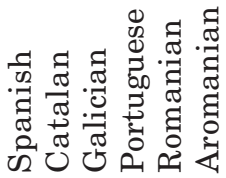
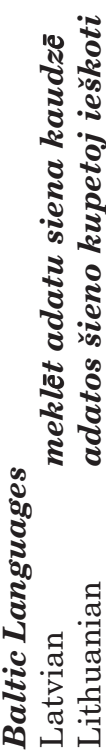

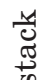

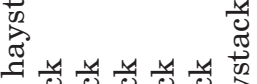

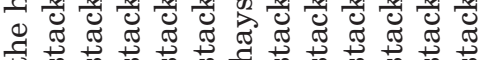

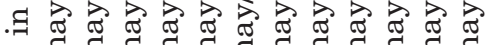

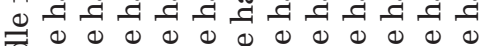

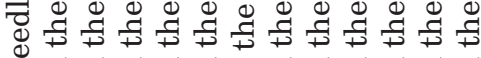

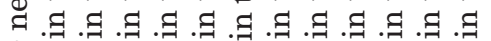

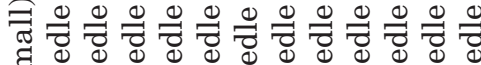
घิ $\pi \sigma \pi \sigma \quad \sigma \quad \sigma \quad \sigma \quad \sigma \quad \sigma \quad \sigma \quad \sigma \quad \sigma \quad \sigma$

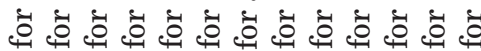

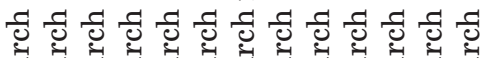
đె

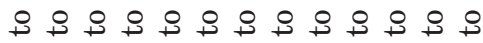

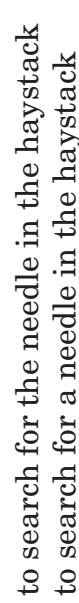

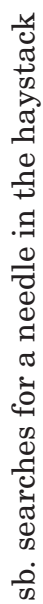

ฐัฐ

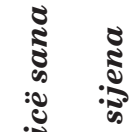

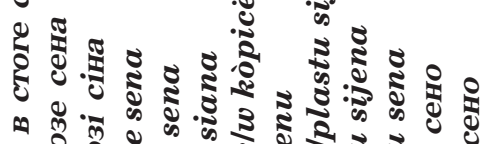

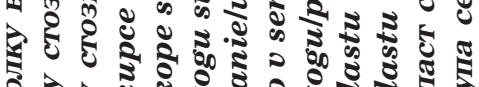

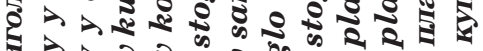

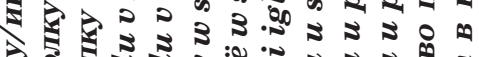

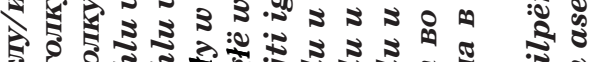

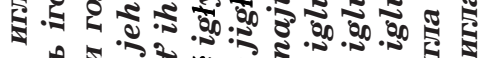

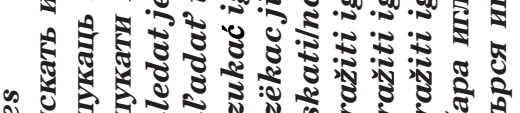

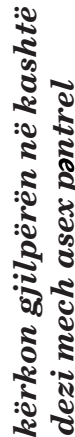

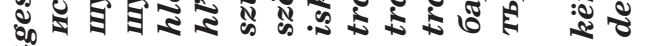

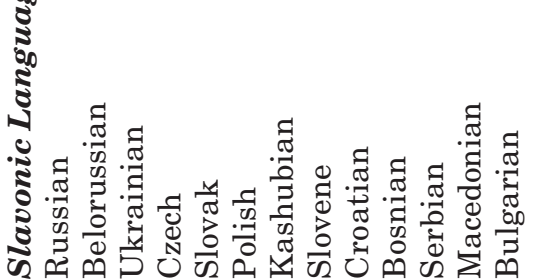

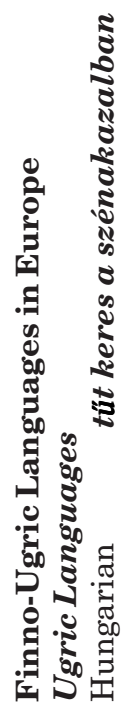



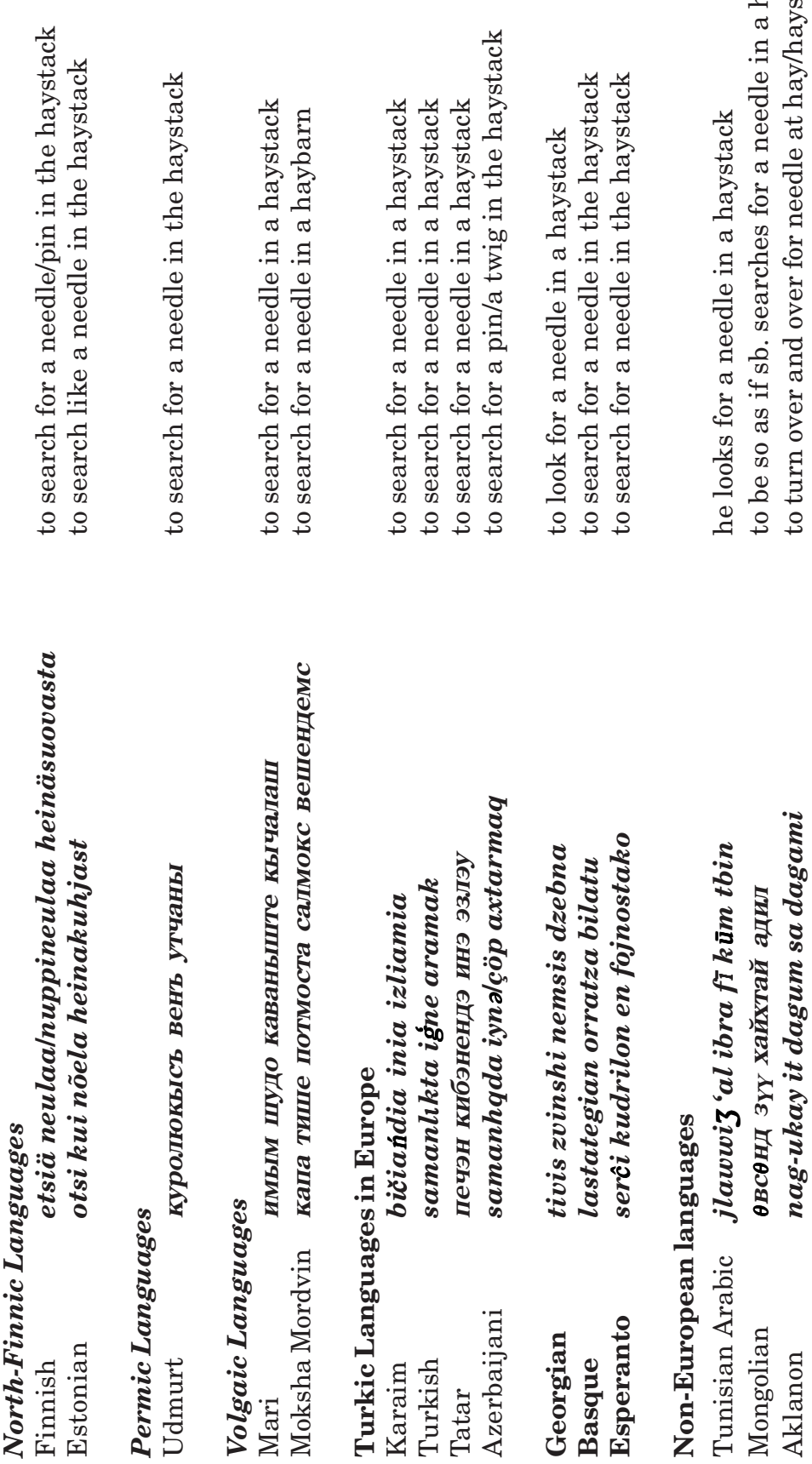


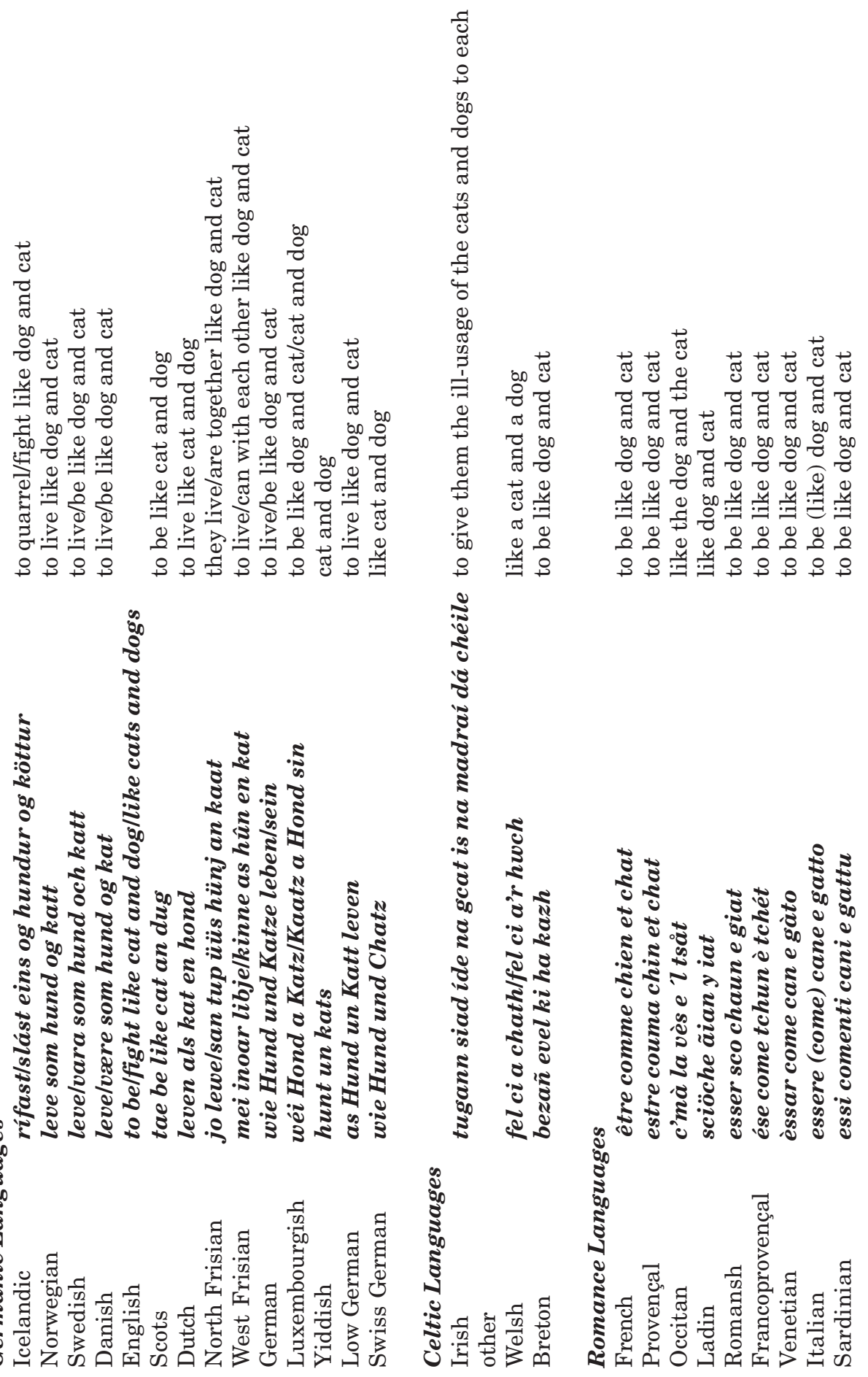



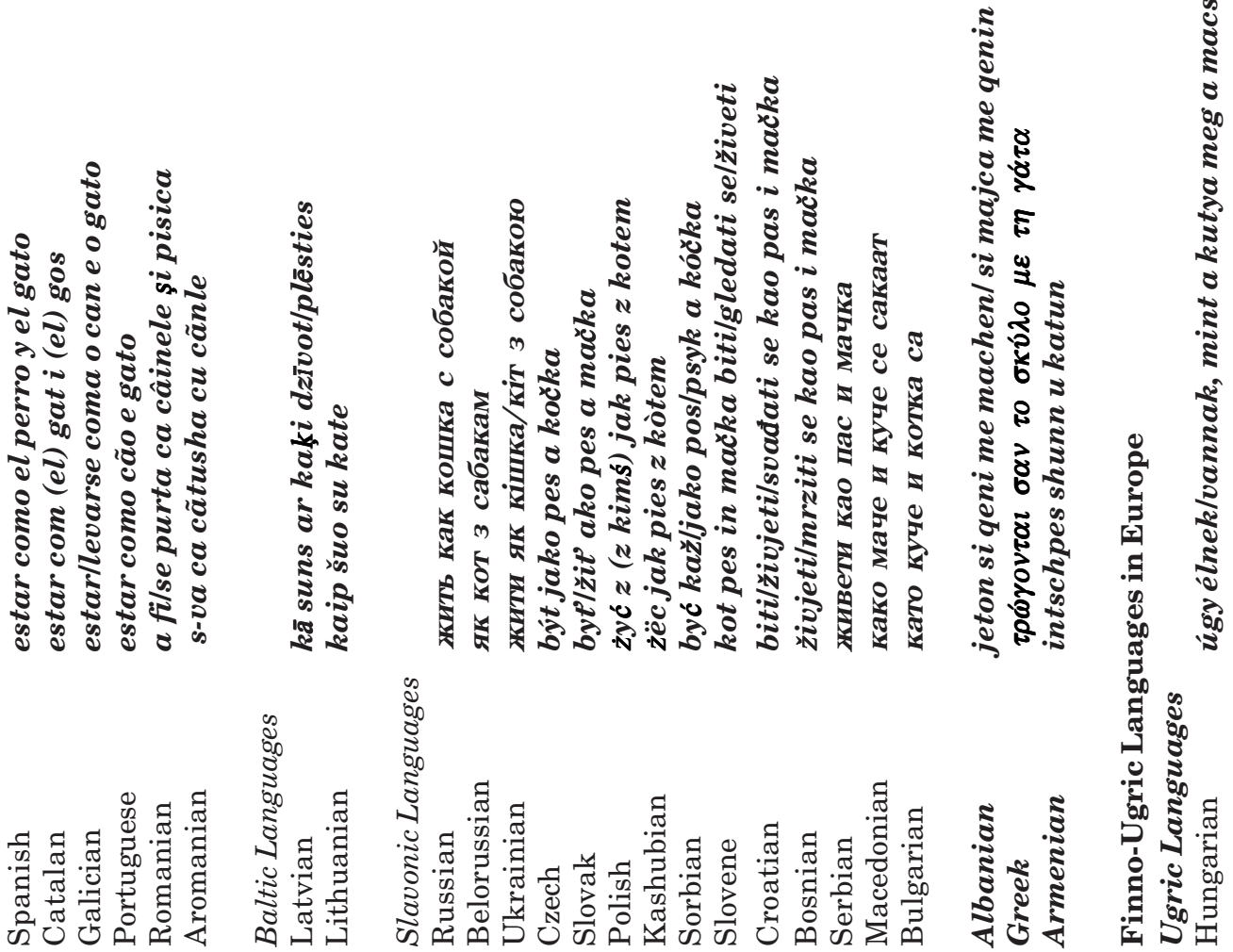

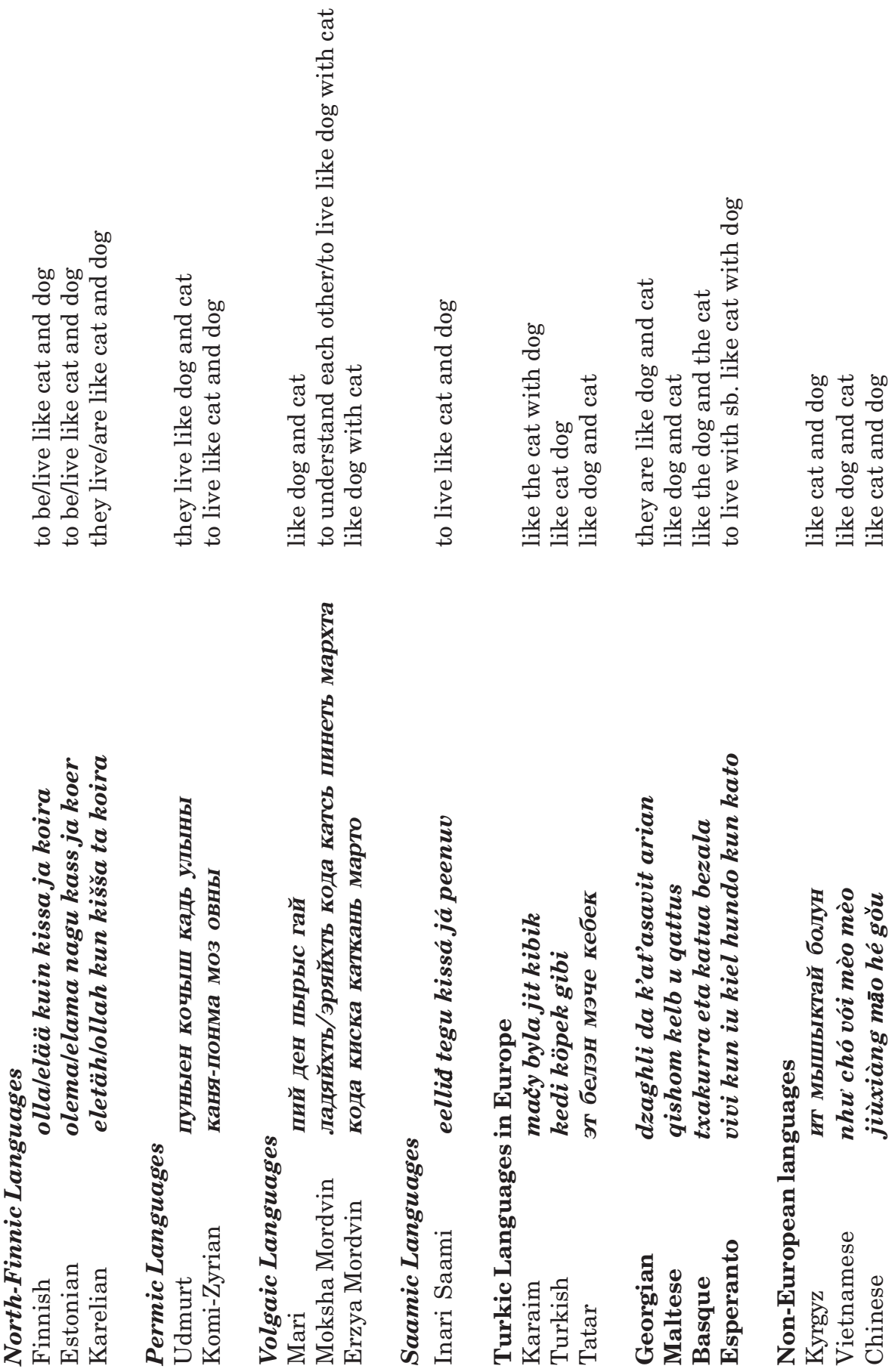

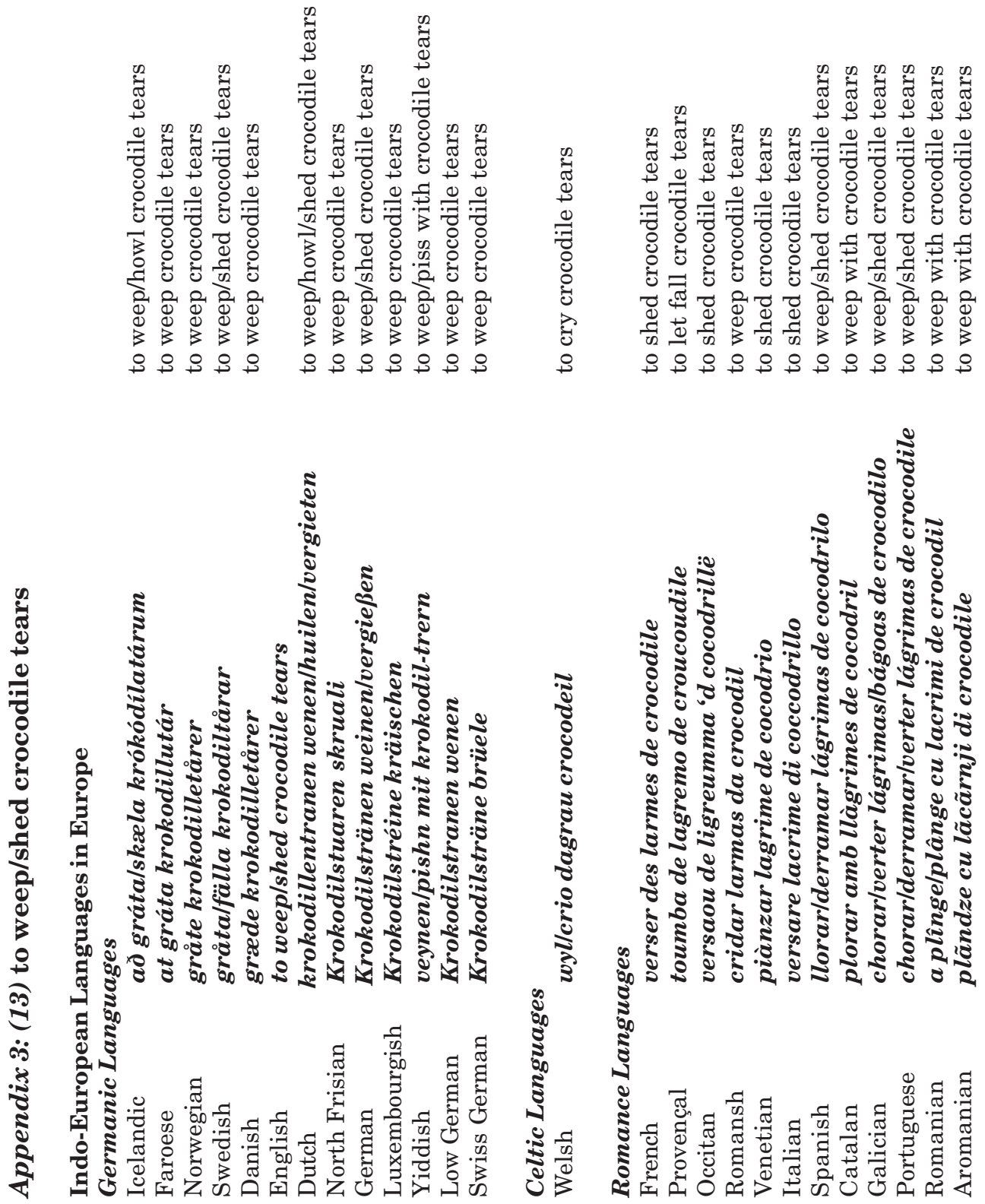

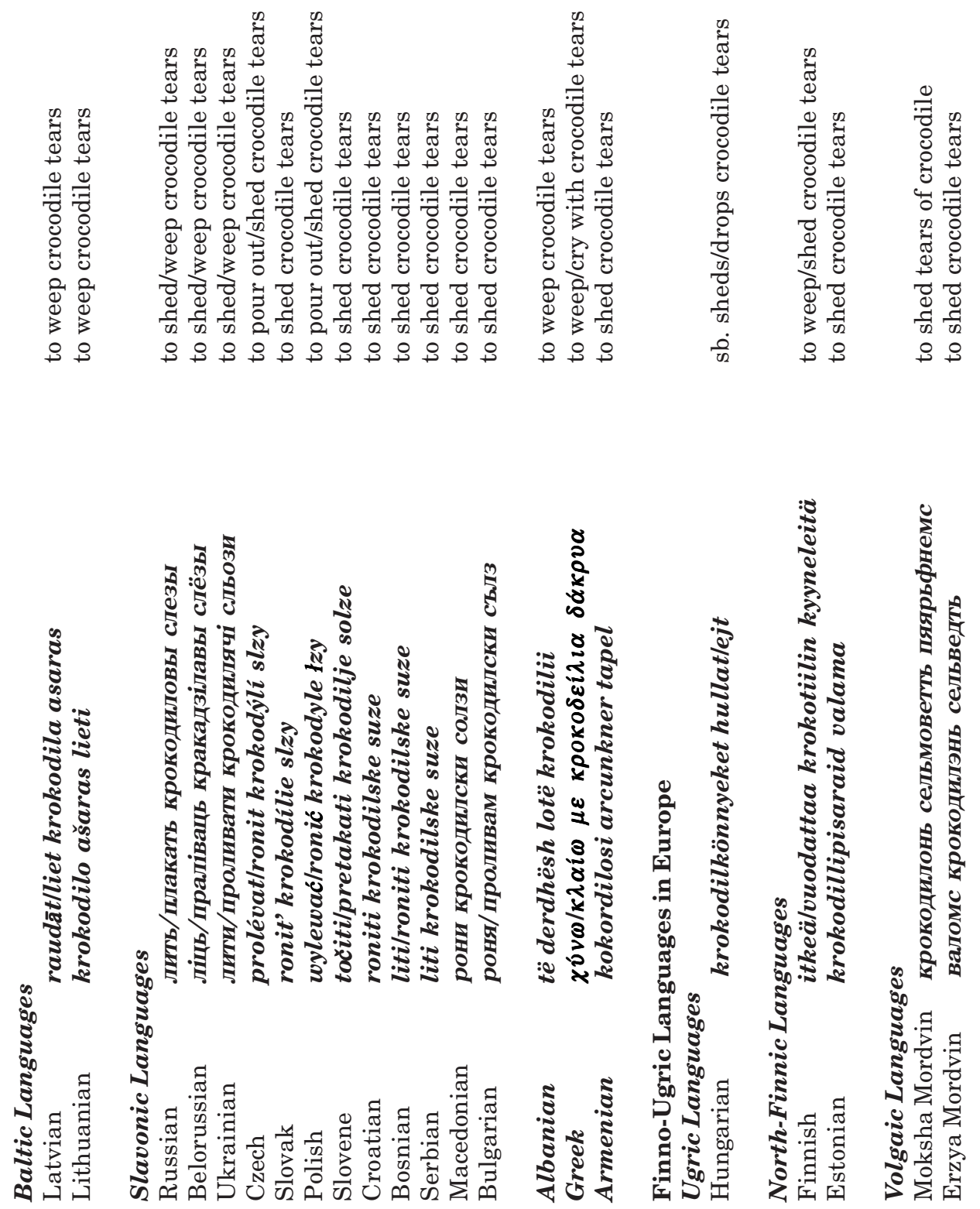

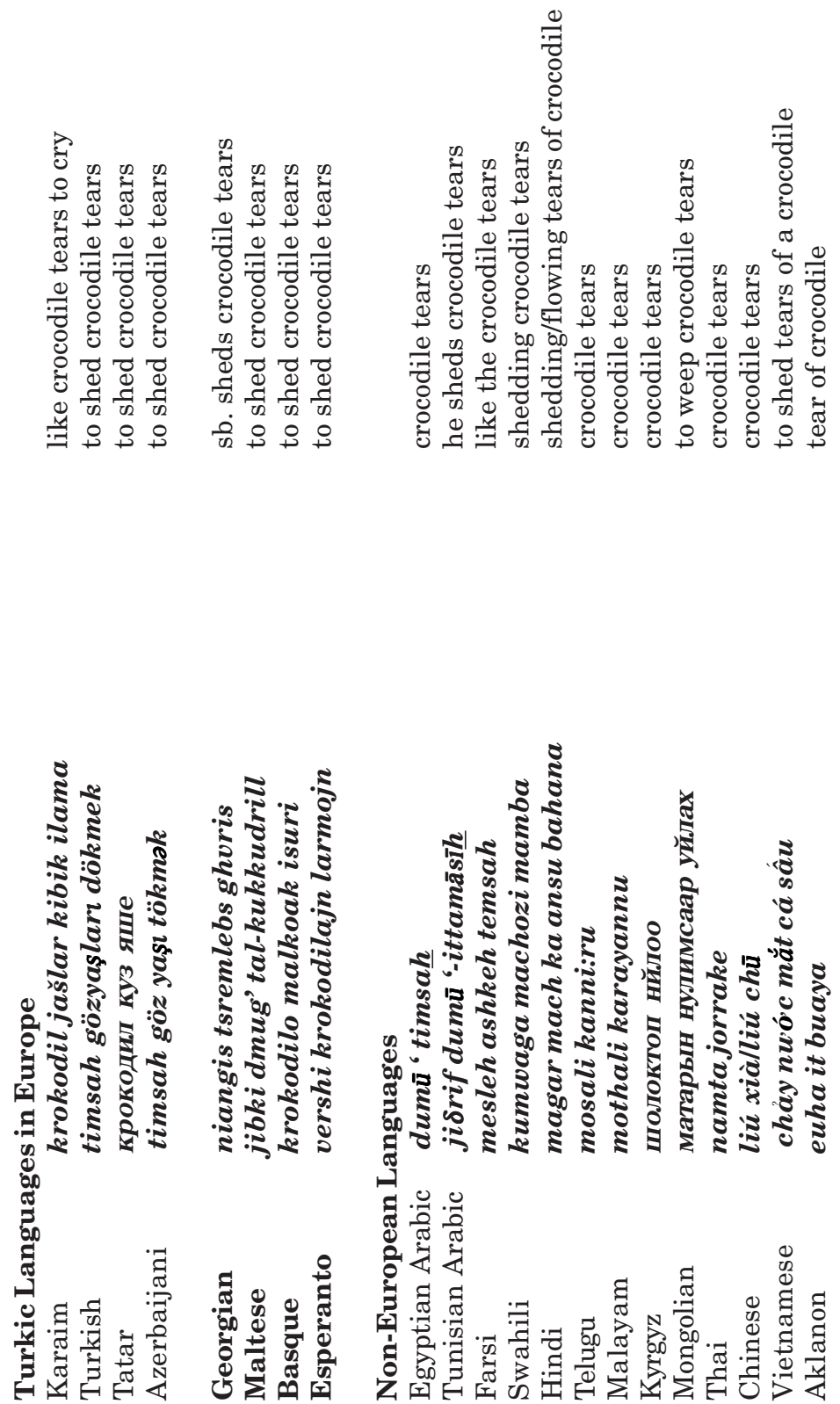


\section{NOTES}

${ }^{1}$ Minor languages like Erzya, Karelian, Komi, Mari, Moksha, Udmurt, Veps and Inari Saami are included in the project, thanks to the great support by Anneli Baran and Terje Keldola from Tartu and Anna Idström from Helsinki with mediating experts.

2 The focus is not so much on "European" because many WIs exist also in non-European languages; cf. also Paczolay 1997.

3 In his Adagia (1.4.32) Erasmus of Rotterdam already suspected that Caesar had reverted to a common proverbial phrase, the correct version of which is alea iacta esto! 'The dice is to be thrown'.

4 There is a number of Greek and Latin proverbs affiliated to this motif (Hansen 2002: 71f; Uther 2004: No. 801, 1180), which found their way into the famous proverb collections (cf. Erasmus' Adagia 1.4.60: cribro aquam haurire) and also came into the vernaculars in this way (cf. AT 1180; TPMA 10, 339f and 12, 137).

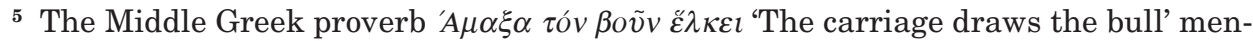
tioned in Diogenianos' Pantodapé lexis (3.30) can be identified in other authors' works, e.g. in Erasmus' Adagia (1.7.28), and in Egbert's Fecunda Ratis (1.317): Ante boues uersum non uidi currere plaustrum 'I did not see running any cart turned before the oxen' (cf. AT 1249; Jones 1989: 201-203; Hansen 2002: 72f; TPMA 9, 334f and $12,312)$.

6 According to Uther (2004 No. 1240) this tale motif goes back to Oriental (IndicArabic) literary sources. See also AT 1240; EM 1, 912ff.

7 See AT 1586, 1586A; Uther 2004 No. 1585; EM 4, 1284ff for more detail.

${ }^{8}$ Comparable ideas are handed down via an Estonian proverb Mine'nd sääske suuretükiga laskma 'Just go and fire with a cannon at a mosquito' and by idioms such as Kashubian wëbrac sã ze seczer na mùchë 'to go with the axe against the fly', Albanian e vret mizën me sëpatë 'to kill the fly with the hatchet' and Bulgarian убивам муха c парен чук 'to kill a fly with a steam hammer'. There is also a Chinese equivalent: $d \grave{a}$ pào dă má què 'to shoot with a cannon at a sparrow'.

9 See also AT 1685; EM 9, $1137 f f$.

${ }^{10}$ See Wesselski 1928: 13-17; Röhrich 1960: 259; AT 200; EM 7, 1104 for more detail.

${ }^{11}$ Cf. Röhrich 1960: 258; TPMA 6, 451; EM 7, 1104f; Moser Karagiannis 2009.

${ }^{12}$ Compare also Tunisian Arabic lu'batu-lqitti wa-lfa'ri 'the game of the cat and the mouse', Vietnamese chò i trò mèo vò $n$ chuột 'to play the game cat-jump around-mouse', Mongolian муур хулгана болох 'to play cat and mouse', Aklanon hampang it kuring ag eanggam 'to play of cat - mouse/rat'.

${ }^{13}$ In Swedish idioms the word råtta 'rat' often occurs where other languages use the word meaning 'mouse'; cf. Blume 2001, see also idiom (9).

${ }^{14}$ See AT 112 and Uther 2004 No. 112 for details.

${ }^{15}$ When the ostrich hen senses danger while it is sitting on the eggs, she will stretch her long neck towards the ground to better blend into the surroundings. 
16 The allusion to the fabled bird can also be identified in the Medieval Latin proverb collection Fecunda Ratis (1, 737).

${ }^{17}$ See Schöne 1993: 73-76; EM 8, 487.

\section{REFERENCES}

Adagia $=$ Collected Works of Erasmus, Vols. 31-36. 1982-2006. Transl. by M. Mann Phillips. Toronto: Toronto University Press.

AT $=$ Aarne, Antti \& Thompson, Stith 1961. The Types of the Folktale. A Classification and Bibliography. Helsinki: Suomalainen Tiedeakatemia.

Blume, Herbert 2001. Katt och råtta, Katz und Maus. Ungleiche lexikalisch-semantische Strukturen im Schwedischen und Deutschen. In: A. Burkhardt \& D. Cherubim (eds.) Sprache im Leben der Zeit: Beiträge zur Theorie, Analyse und Kritik der deutschen Sprache in Vergangenheit und Gegenwart: Helmut Henne zum 65. Geburtstag. Tübingen: Max Niemeyer, pp. 389-399.

Carnes, Pack (ed.) 1988. Proverbia in Fabula: Essays on the Relationship of the Fable and the Proverb. Bern: Peter Lang.

Carnes, Pack 1991. The fable and the proverb: intertexts and reception. Proverbium. Yearbook of International Proverb Scholarship, Vol. 8, pp. 55-76.

Dobrovol'skij, Dmitrij \& Piirainen, Elisabeth 2005. Figurative Language: Cross-cultural and Cross-linguistic Perspectives. Current Research in the Semantics/Pragmatics Interface Vol. 13. Amsterdam: Elsevier.

$\mathrm{EM}=$ Enzyklopädie des Märchens. Handwörterbuch zur historischen und vergleichenden Erzählforschung 2010. Vol. 13. Berlin: de Gruyter.

Fecunda Ratis = Voigt, Ernst 1889. Egberts von Lüttich Fecunda Ratis. Zum ersten Mal Herausgegeben aufihre Quellen zurückgeführt und erklärt von Ernst Voigt. Halle a. S.: Verlag von Max Niemeyer.

Grzybek, Peter 1989. Invariant Meaning Structures in Texts - Proverb and Fable. In: K. Eimermacher \& P. Grzybek \& G. Witte (eds.) Issues in Slavic Literary and Cultural Theory. Studien zur Literatur- und Kulturtheorie in Osteuropa. Bochum: Brockmeyer, pp. 349-389.

Hansen, William F. 2002. Ariadne's Thread: A Guide to International Tales Found in Classical Literature. Ithaca, NY: Cornell University Press.

Jones, Malcolm 1989. Folklore Motifs in Late Medieval Art I: Proverbial Follies and Impossibilities. Folklore, Vol. 100, No. 2, pp. 201-217.

$\mathrm{KHM}=$ Kinder- und Hausmärchen gesammelt durch die Brüder Grimm. Hrsg. von Friedrich von der Leyen. Die Märchen der Weltliteratur. Jena: Diederichs Verlag.

Mieder, Wolfgang 1986. Sprichwörtliche Schwundstufe des Märchens. Proverbium. Yearbook of International Proverb Scholarship, Vol. 3, pp. 257-271.

Mieder, Wolfgang 2010. "Luftschlösser bauen". Traditionelle und innovative Funktion eines redensartlichen Wunschbildes. In: W. Mieder (ed.) "Spruchschlösser (ab)bauen": Sprichwörter, Antisprichwörter und Lehnsprichwörter in Literatur und Medien. Wien: Praesens, pp. 341-362. 
Moser Karagiannis, Emmanuelle 2009. 'Jouer au chat et à la souris'. Etude lexicographique comparée. In: K. Glykioti \& D. Kinne (eds.) Griechisch - EllinikaGrekiska: Festschrift für Hans Ruge. Frankfurt am Main \& New York \& Oxford: Peter Lang, pp. 171-177.

Naturalis historia $=$ Pliny the Elder 1991. Naturalis historia / Naturkunde in 37 Bänden. Lateinisch - Deutsch. München: Artemis und Winkler.

Öberg, Jan 2009. Der Vogel Phönix und Albertus Pictor - ein Fabeltier des archaischen Griechenlands im spätmittelalterlichen Schweden. In: K. Glykioti \& D. Kinne (eds.) Griechisch - Ellinika-Grekiska: Festschrift für Hans Ruge. Frankfurt am Main \& New York \& Oxford: Peter Lang, pp. 179-177.

Paczolay, Gyula 1997. European Proverbs in 55 Languages with Equivalents in Arabic, Persian, Sanskrit, Chinese and Japanese. Veszprém: Veszprémi Nyomda.

Permiakov, Grigorii L. 1979. From Proverb to Folk-tale: Notes on the General Theory of Cliché. Moscow: Nauka.

Perry, Ben Edwin 1959. Fable. Studium Generale, Vol. 12, pp. 17-37.

Physiologos = Sbordone, Francesco (ed.) 1976 [1936]. Physiologus. Nachdruck der Ausgabe Rom. Hildesheim: Olms Verlag.

Piirainen, Elisabeth 2009. Phraseologie aus eurolinguistischer Perspektive: Aufgaben, Methoden, Ergebnisse. Neuphilologische Mitteilungen. Bulletin de la Société Néophilologique, Vol. 60, No. 4, pp. 451-486.

Piirainen, Elisabeth 2010. Common features in the phraseology of European languages: cultural and areal perspectives. In: J. Korhonen et al. (eds.) Phraseologie global - areal - regional. Akten der Konferenz EUROPHRAS 2008 vom 13.-16.8.2008 in Helsinki. Tübingen: Gunter Narr, pp. 15-27.

Piirainen, Elisabeth (forthcoming). Widespread Idioms in Europe and Beyond. Toward a Lexicon of Common Figurative Units. International Folkloristics. New York: Peter Lang.

Röhrich, Lutz 1960. Sprichwörtliche Redensarten aus Volkserzählungen. In: K. Bischoff \& L. Röhrich (eds.) Volk, Sprache, Dichtung. Festgabe für Kurt Wagner. Gießen: Wilhelm Schmitz, pp. 247-275.

Schöne, Albrecht 1993. Emblematik und Drama im Zeitalter des Barock. München: C. H. Beck.

Spalding, Keith 1959-2003. An Historical Dictionary of German Figurative Usage. Oxford: Basil Blackwell.

TPMA = Thesaurus Proverbiorum Medii Aevi: Lexikon der Sprichwörter des romanischgermanischen Mittelalters 1995-2002. Berlin \& New York: De Gruyter.

Trokhimenko, Olga V. 1999. "Wie ein Elefant im Porzellanladen”: Zur Weltgeschichte einer Redensart. Burlington, Vermont: The University of Vermont.

Uther, Hans-Jörg 2004. The Types of International Folktales. A Classification and Bibliography, Based on the System of Antti Aarne and Stith Thompson. Editorial staff: Sabine Dinslage, Sigrid Fährmann, Christine Goldberg, Gudrun Schwibbe. 1: Animal Tales, Tales of Magic, Religious Tales, and Realistic Tales, with an Introduction. (FF Communications 284). Helsinki: Suomalainen Tiedeakatemia.

Wesselski, Albert 1928. Erlesenes. Prague: Gesellschaft deutscher Bücherfreunde in Böhmen. 